\title{
Hydrogeochemical processes in the groundwater environment of Batlagundu block, Dindigul district, Tamil Nadu: conventional graphical and multivariate statistical approach
}

\author{
T. S. R. Umamageswari ${ }^{1}$ (D) D. Sarala Thambavani ${ }^{2} \cdot$ Mitu Liviu $^{3}$
}

Received: 4 November 2016 / Accepted: 27 December 2018 / Published online: 5 January 2019

(c) The Author(s) 2019

\begin{abstract}
Water quality assessment is essential to ensure viable safe use of the resources for drinking, agricultural and industrial purposes. Deterioration of groundwater quality due to anthropogenic activities is increasing at an alarming rate in most parts of Dindigul district, but limited work has been carried out on groundwater quality and monitoring. This paper highlights the groundwater quality and compares its suitability for drinking and irrigation purpose of Batlagundu block in Dindigul district of Tamil Nadu. Eighteen groundwater samples were collected systematically in triplicates during the year 2013-2014. The physical and chemical parameters of the analytical results of groundwater were compared with the standard guideline values recommended by the Bureau of Indian Standards and World Health Organization for irrigational suitability, domestic usage. Further hydrogeochemical data have been plotted in standard graphs such as Piper trilinear diagram, US Salinity Laboratory (USSL), Giggenbach triangle diagram and Schoeller diagram. The mathematical models are used to estimate water quality parameters and to describe realistic water situations. It is proved that electrical conductance is an important water quality parameter. Hydrofacies diagram reported that alkaline earths $\left(\mathrm{Ca}^{2+}\right.$ and $\left.\mathrm{Mg}^{2+}\right)$ significantly exceed the alkalis $\left(\mathrm{Na}^{+}\right.$and $\left.\mathrm{K}^{+}\right)$, while acids of $\left(\mathrm{Cl}^{-}\right.$and $\left.\mathrm{HCO}_{3}{ }^{-}\right)$exceed the acids of $\left(\mathrm{SO}_{4}{ }^{2-}\right.$ and $\left.\mathrm{CO}_{3}{ }^{2-}\right)$. Therefore, the chemical compositions of the study area were characterized by the $\mathrm{Ca}-\mathrm{Mg}-\mathrm{HCO}_{3}$ water type and $\mathrm{Na}-\mathrm{Cl}$ type. USSL diagram of the study area revealed that most of the sampling sites possess high salinity and low-to-medium sodium hazard indicated that water samples are poorly suitable for usual agropurposes. Giggenbach triangular diagram indicated that the samples have not gained equilibrium with their host rocks, presumably due to fact circulation of fluid through the rock features. The present research work thus concludes that groundwater in the study area is chemically unsuitable for domestic and agricultural uses. It is recommended to carry out a continuous water quality monitoring program and development of effective management practices for utilization of water resources.
\end{abstract}

Keywords Piper · USSL · Giggenbach · Schoeller · Groundwater · Batlagundu

\section{Introduction}

Water, the elixir of life, is a prime natural resource, a basic human need and a precious national asset. A drop of water is worth more than a sack of gold to a thirsty man. "No life without water" is a common saying depending upon the

\section{T. S. R. Umamageswari}

umamageswaritsr1980@gmail.com

1 PSNA College of Engineering and Technology, Dindigul, India

2 Sri Meenakshi Govt Arts College for Women, Madurai, India

3 University of Pitesti, 11040 Pitesti, Romania fact that water is the one of the naturally occurring essential requirement of all life supporting activities (Ayibatatele 1992). Groundwater is the principal source of drinking water in our country and indispensable source of our life. Groundwater has unique features which rendered them suitable for public water supply. They have excellent natural quality usually free from pathogens; color and turbidity can be consumed directly without treatment (Jain et al. 1996a). The healthy aquatic ecosystem is depended on physical, chemical and biological characteristics (Venkatesharaju et al. 2010). Drinking water quality is affected by the presence of different soluble salts (Sonawane and Khole 2010). As the population increases, the water demand for industrial, domestic and agricultural uses increases too. When these demands 
exceed the naturally renewable supply, water shortage occurs in the area (Jamshidzadeh and Mirbagheri 2011). The major problem with the groundwater is that once contaminated, it is difficult to restore its quality. Groundwater is highly valued because of certain properties which are not possessed by surface water (Goel 2000).

Every year, 2, 70,100 million tons of water is required because of 90 million increasing population and approximately 25 million persons die as a result of water pollution. Tamil Nadu accounts for $4 \%$ of the land area and $6 \%$ of the population, but only $3 \%$ of the water resources of the country. Most of Tamil Nadu is located in the rain shadow region of the Western Ghats and hence receives limited rainfall from the southwest monsoon. Chopra and Krishan (2014) and Singh et al. (2011) reported that about $47 \%$ of the groundwater is unfit for drinking and agricultural purposes due to high salinity. The quality of water for irrigation is determined by the concentration and composition of dissolved ions which are generally governed by lithology of subsurface, velocity and quantity of groundwater flow, nature of geochemical reactions, solubility of salts and various anthropogenic activities (Tamma et al. 2015). Groundwater quality variation is a function of physical and chemical patterns in an area influenced by geological and anthropogenic activities (Subramani et al. 2005).

Importance of hydrochemistry of groundwater has led to a number of detailed studies on groundwater quality deterioration and geochemical evolution of groundwater in many parts of the globe (Anku et al. 2009; Gupta et al.2008; Jayasena et al. 2008; Irfan and Said 2008; Kumar et al.2009; Kannan and Joseph 2009; Zhang et al. 2011; Prasanna et al. 2011; Tyagi et al. 2009; Srinivasamoorthy et al. 2009; Vasanthavigar et al. 2012; Sarala Thambavani and Uma Mageswari 2014). Mapping the spatial distributions of major elements and their interpolation with the geology and land use/land cover maps in GIS environment (Zhang et al. 2013) has contributed for the better understanding of the chemical processes of water and the methods of their acquisition. Health problems such as cancer, fluorosis and gastrointestinal irritation were also reported in many studies. Fluoride occurs naturally in groundwater and provides protection against dental caries, especially in children, but the fluoride concentration less than $0.5 \mathrm{mg} / \mathrm{L}$ leads to the risk of tooth decay, while higher concentration causes dental fluorosis (Thivya et al. 2015). Sarala Thambavani and Uma Mageswari (2013) reported the heavy metal contamination in groundwater. Multivariate statistical analysis has been successfully applied in a number of hydrogeochemical studies (Omo-Irabor et al. 2008).

The economy of the study area is mostly dependent on the agriculture. Groundwater is one of the major sources of drinking water in the study area. Therefore, it was imperative to initiate this study to assess the problem and mitigation methods for water contamination. In this study, hydrogeological and hydrochemical information from the groundwater system is integrated and used to determine the main factors and mechanisms controlling the chemistry of groundwater in the area. A periodic monitoring of water quality is essential to understand the quality degradation and also to plan the remedial measures to control further damage. So far, the geochemistry of groundwater and its suitability for drinking and agricultural rationale have not been endeavored in the present study area in great aspect; hence, an effort has been made here to exemplify water/rock interaction and anthropogenic influences on groundwater chemistry.

\section{Materials and methods}

\section{Study area}

Dindigul is a district which has administrative divisions of 7 taluks, 14 blocks, 539 Panchayats and 341 villages. Batlagundu is one of the blocks in Dindigul district. It is geographically located at longitude and latitude of $77^{\circ} 45^{\prime} 33.84^{\prime \prime} \mathrm{E}$ and $10^{\circ} 9^{\prime} .80^{\prime \prime} \mathrm{N}$ with an average elevation of $320 \mathrm{~m}$ above the mean sea level (1049 feet). It encompasses an area of about $190.74 \mathrm{~km}^{2}$. The source of water supply in the area is hand pumps, boreholes and dug wells. The precipitation which is the sole source of groundwater recharges in the study area is very low due to less rainfall. The area is very humid (86\%) and warm with an average temperature of $22{ }^{\circ} \mathrm{C}$. Map of the study area is given in Fig. 1. The description of sampling sites is given in Table 1 .

\section{Geology}

Batlagundu is situated on the boundaries of Dindigul, Theni and Madurai districts. The study area is characterized by highly deformed rocks, which can be classified under three groups as (1) Khondalite group, (2) Charnockite group and (3) Migmatite complex. Khondalite group comprises quartzite, crystalline limestone. Charnockite group comprises pyroxene granulite and charnockite. Migmatite complex is represented by hornblende-biotite gneiss, granitic gneiss and pink migmatite.

\section{Geomorphology}

The geological formation has given rise to various landforms such as structural hills, residual hills, linear ridges and pediment terrains in the study area. Shallow buried pediments and pediments are the results of denudational landforms and are encountered in major parts of the area. 
Fig. 1 Map of the study area

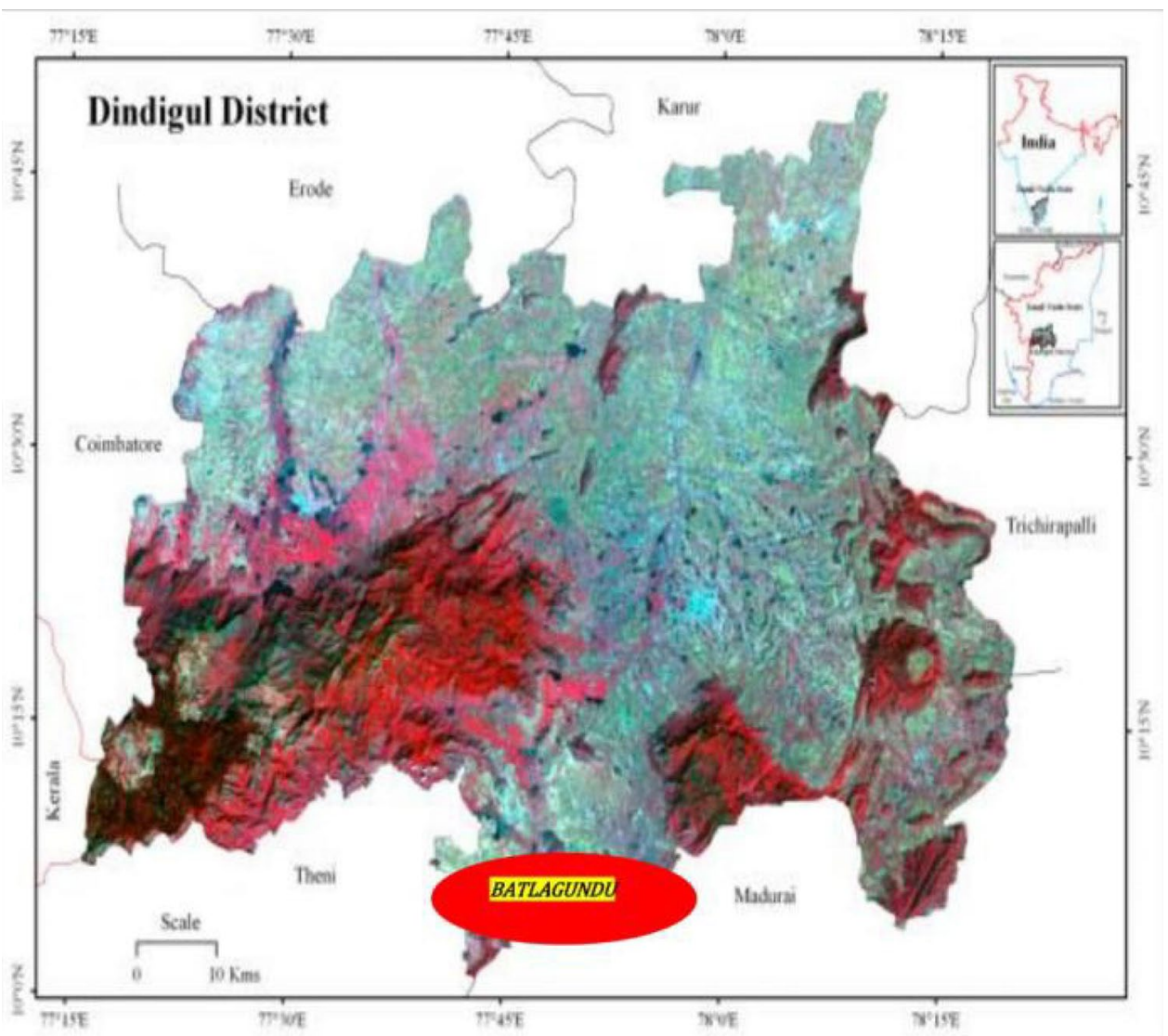

Table 1 Description of sampling sites of Batlagundu block in Dindigul district

\begin{tabular}{llll}
\hline Longitude & Latitude & Place & Site no \\
\hline $77^{\circ} 51^{\prime} 11.60^{\prime \prime} \mathrm{E}$ & $10^{\circ} 9^{\prime} 53.01^{\prime \prime} \mathrm{N}$ & Nilakottai & $\mathrm{S}_{1}$ \\
$77^{\circ} 45^{\prime} 40.24^{\prime \prime} \mathrm{E}$ & $10^{\circ} 10^{\prime} 0.32^{\prime \prime} \mathrm{N}$ & Mallanampatti & $\mathrm{S}_{2}$ \\
$77^{\circ} 45^{\prime} 41.99^{\prime \prime} \mathrm{E}$ & $10^{\circ} 11^{\prime} 9.98^{\prime \prime} \mathrm{N}$ & Usilampatti Road, & $\mathrm{S}_{3}$ \\
$77^{\circ} 45^{\prime} 42.39^{\prime \prime} \mathrm{E}$ & $10^{\circ} 11^{\prime} 10.23^{\prime \prime} \mathrm{N}$ & Anna Nagar, Batlagundu & $\mathrm{S}_{4}$ \\
$77^{\circ} 45^{\prime} 33.84^{\prime \prime} \mathrm{E}$ & $10^{\circ} 9^{\prime} 55.80^{\prime \prime} \mathrm{N}$ & Middle Street, Batlagundu & $\mathrm{S}_{5}$ \\
$77^{\circ} 45^{\prime} 33.99^{\prime \prime} \mathrm{E}$ & $10^{\circ} 9^{\prime} 56.05^{\prime \prime} \mathrm{N}$ & Periyakulam Road, Bat- & $\mathrm{S}_{6}$ \\
& & lagundu & \\
$77^{\circ} 75^{\prime} 93.04^{\prime \prime} \mathrm{E}$ & $10^{\circ} 16^{\prime} 11.89^{\prime \prime} \mathrm{N}$ & Vegetable Market & $\mathrm{S}_{7}$ \\
$77^{\circ} 75^{\prime} 90.88^{\prime \prime} \mathrm{E}$ & $10^{\circ} 16^{\prime} 37.60^{\prime \prime} \mathrm{N}$ & Coir Industry & $\mathrm{S}_{8}$ \\
$77^{\circ} 77^{\prime} 29.57^{\prime \prime} \mathrm{E}$ & $10^{\circ} 15^{\prime} 90.73^{\prime \prime} \mathrm{N}$ & M.Vadipatti & $\mathrm{S}_{9}$ \\
$77^{\circ} 55^{\prime} 56.97^{\prime \prime} \mathrm{E}$ & $10^{\circ} 11^{\prime} 45.03^{\prime \prime} \mathrm{N}$ & Salaipudur & $\mathrm{S}_{10}$ \\
$77^{\circ} 57^{\prime} 43.24^{\prime \prime} \mathrm{E}$ & $10^{\circ} 15^{\prime} 70.75^{\prime \prime} \mathrm{N}$ & Food processing industry & $\mathrm{S}_{11}$ \\
$77^{\circ} 65^{\prime} 13.89^{\prime \prime} \mathrm{E}$ & $10^{\circ} 11^{\prime} 34.60^{\prime \prime} \mathrm{N}$ & Bodikamanvadi & $\mathrm{S}_{12}$ \\
$77^{\circ} 45^{\prime} 89.47^{\prime \prime} \mathrm{E}$ & $10^{\circ} 11^{\prime} 65.09^{\prime \prime} \mathrm{N}$ & Boystown & $\mathrm{S}_{13}$ \\
$77^{\circ} 13^{\prime} 67.90^{\prime \prime} \mathrm{E}$ & $10^{\circ} 15^{\prime} 05.87^{\prime \prime} \mathrm{N}$ & Ghatroad & $\mathrm{S}_{14}$ \\
$77^{\circ} 34^{\prime} 56.12^{\prime \prime} \mathrm{E}$ & $10^{\circ} 15^{\prime} 09.06^{\prime \prime} \mathrm{N}$ & Attanampatty & $\mathrm{S}_{15}$ \\
$77^{\circ} 46^{\prime} 23.45^{\prime \prime} \mathrm{E}$ & $10^{\circ} 11^{\prime} 78.23^{\prime \prime} \mathrm{N}$ & Temple & $\mathrm{S}_{16}$ \\
$77^{\circ} 34^{\prime} 67.67^{\prime \prime} \mathrm{E}$ & $10^{\circ} 18^{\prime} 90.73^{\prime \prime} \mathrm{N}$ & Devathanapatty & $\mathrm{S}_{17}$ \\
$77^{\circ} 43^{\prime} 17.07^{\prime \prime} \mathrm{E}$ & $10^{\circ} 18^{\prime} 90.73^{\prime \prime} \mathrm{N}$ & Nallakaruppanpatty & $\mathrm{S}_{18}$ \\
\hline
\end{tabular}

\section{Drainage}

The southern part of the study area falls under Vaigai subbasin. The important rivers are Manjalar and Vaigai River. These are also ephemeral in nature and receive flow during monsoon period only. In the major part of the study area, the drainage pattern is subdentritic and dentritic. Radial and parallel drainage patterns are also in the study area. Most of the streams are structurally controlled.

\section{Hydrogeology}

The important aquifer systems encountered in the study area are classified into (1) fissured, fractured and weathered crystalline formations consisting of Charnockites, Granite Gneisses and (2) Valley fill sediments (unconsolidated sediments) comprising clay, sand, silt and kankar.

\section{Sample collection and analysis of groundwater}

Groundwater samples currently in use were selected based on the preliminary field survey carried out to understand the overall distribution of various types of groundwater in the study area. The selected samples are used for domestic and agricultural purposes and are uniformly distributed over 
the area of concern. Groundwater samples were collected using global positioning system (GPS). A total of 18 water samples were collected from existing hand pumps, bore wells and tube wells tapping different depths and covering different parts of the study area. The groundwater samples were collected during monsoon in the year 2013 and 2014 in triplicates. Out of 18 samples, $10 \%$ of samples had a depth to water level in the range of $0-2 \mathrm{~m} \mathrm{bgl}, 40 \%$ in the range of $2-5 \mathrm{~m} \mathrm{bgl}, 45 \%$ in the range of $10-20 \mathrm{~m} \mathrm{bgl}$ and $5 \%$ more than $20 \mathrm{~m}$ bgl. These samples were collected using 4-1 acid-washed polypropylene containers. Each sample was immediately filtered onsite through $0.45 \mu \mathrm{m}$ filters on acetate cellulose. The samples were analyzed in the laboratory for their chemical constituents using standard methods as suggested by APHA, AWWA, WPCF (2005), NEERI (1986) and Trivedy and Goel (1984) given in Table 2. The experimental values were compared with standard values recommended by World Health Organization (WHO 2004) and Indian standards for drinking purposes (BIS 1999) given in Table 3.

\section{Correlation analysis between physicochemical parameters}

Multivariate statistical analysis can be used to assess the complex ecotoxicological processes by showing the relationship and interdependency among the variables and their relative weights. The mathematical models are used to estimate water quality parameters and to describe realistic water situations. Correlation analysis measures the closeness of the relationship between chosen dependent and independent variables. If the correlation coefficient is nearer to +1 or -1 , it shows the probability of linear relationship between the variables $X$ and $Y$. In this study, the relationship of water quality parameters on each other was determined by calculating Karl Pearson's correlation coefficient " $r$ " by using the formula as given below:

$r=\frac{\sum(X-\bar{X})(Y-\bar{Y})}{\sqrt{(X-\bar{X})^{2}(Y-\bar{Y})^{2}}}$

If the values of correlation coefficient " $r$ " between the two variables $X$ and $Y$ are fairly large, then it implies that

Table 2 Water quality parameters units and analytical methods used

\begin{tabular}{|c|c|c|c|c|c|}
\hline S. no & Parameters & Abbreviation & Units & Analytical methods & Instruments \\
\hline \multicolumn{6}{|c|}{ Physical parameters } \\
\hline 1. & Temperature & Temp & ${ }^{\circ} \mathrm{C}$ & Instrumental & Mercury thermometer \\
\hline 2. & Color & Color & Pt-Co scale & Visual comparison method & - \\
\hline 3. & Turbidity & Turbidity & NTU & Nephelometric method & Nephelometer \\
\hline 4. & Total dissolved solids & TDS & $\mathrm{mg} / \mathrm{L}$ & Filtration and gravimetric method & Temperature-controlled oven \\
\hline 5. & Electrical conductivity & $\mathrm{EC}$ & $\mu \mathrm{S} / \mathrm{cm}$ & Instrumental & Electrometric \\
\hline \multicolumn{6}{|c|}{ Inorganic parameters } \\
\hline 6. & $\mathrm{pH}$ & $\mathrm{pH}$ & $\mathrm{pH}$ unit & Instrumental & $\mathrm{pH}$ meter \\
\hline 7. & Total hardness & Hardness & $\mathrm{mg} / \mathrm{L}$ & Digital titrimetric & EDTA titration \\
\hline 8. & Total alkalinity & Alkalinity & $\mathrm{mg} / \mathrm{L}$ & Digital titrimetric & Neutralizing with standard $\mathrm{HCl}$ \\
\hline 9. & Calcium & $\mathrm{Ca}$ & $\mathrm{mg} / \mathrm{L}$ & Digital titrimetric & EDTA titration \\
\hline 10. & Magnesium & $\mathrm{Mg}$ & $\mathrm{mg} / \mathrm{L}$ & Digital titrimetric & EDTA titration \\
\hline 11. & Chloride & $\mathrm{Cl}$ & $\mathrm{mg} / \mathrm{L}$ & Digital titrimetric & Argentometric Titrimetric method \\
\hline 12. & Sulfate & $\mathrm{SO}_{4}$ & $\mathrm{mg} / \mathrm{L}$ & Colorimetric turbidimetric method & UV-Vis Spectrophotometer \\
\hline 13. & Nitrate & $\mathrm{NO}_{3}$ & $\mathrm{mg} / \mathrm{L}$ & Colorimetric PDA method & UV-Vis spectrophotometer \\
\hline 14. & Nitrite & $\mathrm{NO}_{2}$ & $\mathrm{mg} / \mathrm{L}$ & Diazotization method & UV-Vis spectrophotometer \\
\hline 15. & Fluoride & $\mathrm{F}$ & $\mathrm{mg} / \mathrm{L}$ & Colorimetric SPANDS method & UV-Vis spectrophotometer \\
\hline 16. & Sodium & $\mathrm{Na}$ & $\mathrm{mg} / \mathrm{L}$ & Flame photometric method & Flame photometer \\
\hline 17. & Potassium & $\mathrm{K}$ & $\mathrm{mg} / \mathrm{L}$ & Flame photometric method & Flame photometer \\
\hline 18. & Ammonia & $\mathrm{NH}_{3}$ & $\mathrm{mg} / \mathrm{L}$ & Nesslerization method & UV-Vis spectrophotometer \\
\hline \multicolumn{6}{|c|}{ Nutrient/organic parameters } \\
\hline 19. & Phosphate & $\mathrm{PO}_{4}$ & $\mathrm{mg} / \mathrm{L}$ & Colorimetric stannous chloride method & UV-Vis spectrophotometer \\
\hline 20. & Dissolved oxygen & DO & $\mathrm{mg} / \mathrm{L}$ & Titrimetric method & Winklers iodometric method \\
\hline 21. & Biochemical oxygen demand & BOD & $\mathrm{mg} / \mathrm{L}$ & 5 days incubation, $20^{\circ} \mathrm{C}$ & Winkler azide method \\
\hline 22 & Chemical oxygen demand & COD & $\mathrm{mg} / \mathrm{L}$ & $\begin{array}{l}\text { Potassium dichromate oxidation (open } \\
\text { reflux, titrimetric) }\end{array}$ & Dichromate method \\
\hline
\end{tabular}


Table 3 Statistical summary of the physicochemical parameters of groundwater samples collected from the study area

\begin{tabular}{|c|c|c|c|c|c|c|}
\hline S. no & Parameters & BIS (1999) & WHO (2004) & Maximum & Minimum & Mean \\
\hline 1 & Temp $\left({ }^{\circ} \mathrm{C}\right)$ & - & $40 \pm 5$ & 23.1 & 16.8 & 19.95 \\
\hline 2 & Turbidity (NTU) & 5.0 & 5.0 & 5 & 1 & 3.0 \\
\hline 3 & TDS & 500 & 1000 & 2130 & 462 & 1296 \\
\hline 4 & $\mathrm{EC}(\mu \mathrm{mho} / \mathrm{cm})$ & - & 300 & 3132 & 679 & 1905.5 \\
\hline 5 & $\mathrm{pH}$ & $6.5-8.5$ & $6.5-8.5$ & 8.04 & 6.87 & 7.4 \\
\hline 6 & $\mathrm{TH}$ & 300 & 500 & 900 & 220 & 560 \\
\hline 7 & TA & 200 & - & 400 & 180 & 290 \\
\hline 8 & $\mathrm{Ca}^{2+}$ & 75 & - & 200 & 42 & 121 \\
\hline 9 & $\mathrm{Mg}^{2+}$ & 30 & 30 & 96 & 22 & 59 \\
\hline 10 & $\mathrm{Cl}^{-}$ & 250 & 250 & 780 & 80 & 430 \\
\hline 11 & $\mathrm{SO}_{4}^{2-}$ & 200 & 400 & 146 & 25 & 85.5 \\
\hline 12 & $\mathrm{NO}_{3}^{-}$ & 45 & 10 & 19 & 05 & 12 \\
\hline 13 & $\mathrm{NO}_{2}^{-}$ & 0.06 & - & 0.38 & 0.12 & 0.25 \\
\hline 14 & $\mathrm{~F}^{-}$ & 1.0 & 1.5 & 2.0 & 0.4 & 1.2 \\
\hline 15 & $\mathrm{Na}^{+}$ & - & 200 & 336 & 42 & 189 \\
\hline 16 & $\mathrm{~K}^{+}$ & - & 200 & 84 & 12 & 48 \\
\hline 17 & $\mathrm{NH}_{3}$ & - & - & 0.73 & 0.18 & 0.45 \\
\hline 18 & $\mathrm{PO}_{4}{ }^{3-}$ & - & 5.0 & 1.0 & 0.3 & 0.65 \\
\hline 19 & DO & - & $>5$ & 8.1 & 5.0 & 6.55 \\
\hline 20 & BOD & - & 5 & 2.3 & 1.0 & 1.65 \\
\hline 21 & COD & - & 20 & 6.9 & 3.0 & 4.95 \\
\hline
\end{tabular}

All parameters are expressed in mg/L except Temp, Turbidity, EC and $\mathrm{pH}$ these variables are highly correlated. In such cases, it is fissile to try linear relation in the form:

$Y=a+b X$

The value of empirical parameters $a$ and $b$ are calculated with the help of the following equation:

$b=\frac{\sum X Y-\bar{X} \sum Y}{\sum X^{2}-\bar{X} \sum X}$

$a=\bar{Y}-b \bar{X}$

where $\bar{X}=$ mean of all values of $X$ and $\bar{Y}=$ mean of all values of $Y$.

To study the correlation between various water quality parameters, the regression analysis was carried out using computer software SPSS, version-15.

\section{Hydrofacies diagram}

\section{Piper trilinear diagram (Piper 1944)}

Piper trilinear diagram is a graphical method of representation of chemical analysis. It is based on the concentration of dominant cations and anions. This trilinear diagram was proposed to show the percentages at milliequivalents per liter of cations and anions in water samples. The Piper trilinear diagram is very useful in bringing out chemical relationships among groundwater in more definite terms. This is useful to understand the total chemical character of water samples in terms of cation-anion pairs.

The Piper diagram consists of two triangular and one intervening diamond-shaped field. All three sides of the two triangular fields and the four sides of the diamond-shaped field are divided into 100 parts. The percentage reacting values at the three cation groups $\mathrm{Ca}^{2+}, \mathrm{Mg}^{2+}$ and $\left(\mathrm{Na}^{+}+\mathrm{K}^{+}\right)$are plotted as a single point in the left triangular field and the three anion groups $\left(\mathrm{HCO}_{3}{ }^{-}+\mathrm{CO}_{3}{ }^{2-}\right), \mathrm{SO}_{4}{ }^{2-}$ and $\mathrm{Cl}^{-}$similarly on the right triangular field. The two points in each triangular field show the relative concentration of several dissolved constituents of the water sample. Later, a third point is plotted in the central diamond-shaped field after computing percentage reacting values for anions and cations separately. This field shows the complete chemical character of the water samples that gives the relative composition of groundwater about the cation-anion pairs. These three fields reflect the chemical character of groundwater according to the relative concentration of its constituent but not according to the absolute concentrations.

\section{USSL diagram for irrigation water quality evaluation}

The well-known diagram for classifying irrigation water was suggested by US Salinity Laboratory Staff (1954) that is 
called as USSL diagram. The USSL diagram explains the combined effect of sodium hazard and salinity hazard. It is a simple scatter chart of sodium hazard (SAR) on the $Y$-axis versus salinity hazard (EC) on the $X$-axis. The $\mathrm{EC}$ is plotted by default on a log scale. Water is divided into four classes with respect to electrical conductance, the dividing points between classes being at 250,750 and $2250 \mu \mathrm{mhos} / \mathrm{cm}$. These classes were selected in accordance with the relationship between the electrical conductance of irrigation water and electrical conductance of saturation extracts of soil.

The curves of diagram can be constructed by the use of the following empirical equations (US Salinity Laboratory Staff 1954)

Upper curve : $\mathrm{S}=43.75-8.87(\log \mathrm{C})$

Middle curve: $\mathrm{S}=31.31-6.66(\log \mathrm{C})$

Lower curve $: S=18.87-4.44(\log C)$

where $\mathrm{S}, \mathrm{C}$ and $\log$ are abbreviation of sodium absorption ratio (SAR), electrical conductance (EC), in micromhos per centimeter and logarithm to base 10, respectively. These equations plot as straight lines on rectangular coordinate paper when $\log \mathrm{C}$ is used.

Using the SAR and the EC value as coordinate, the corresponding point is located on the diagram. The position of the point determines the quality classification of the water. The significance and interpretation of the quality class ratings on the diagram are summarized as follows:

For purposes of determination and classification, the total concentration of soluble salts (Salinity hazard) in irrigation water can be adequately expressed in terms of specific conductance. Based on the EC, irrigation water can be classified into four categories as follows:

(1) Low salinity water $\left(\mathrm{C}_{1}\right)$ can be used for irrigation for all crops on all types of soil. Leaching is required under normal irrigation practices, except in soils of extremely low permeability.

(2) Medium salinity water $\left(\mathrm{C}_{2}\right)$ can be used if a moderate amount of leaching occurs. Plants with moderate salt tolerance can be grown in most instances without special practices of salinity control.

(3) High salinity water $\left(\mathrm{C}_{3}\right)$ cannot be used on soils with restricted drainage. Even with adequate drainage, special management for salinity control may be required and plants with good salt tolerance should be selected.

(4) Very high salinity water $\left(\mathrm{C}_{4}\right)$ is not suitable for irrigation under ordinary conditions, but may be used occasionally, under very special circumstances. The soil must be permeable, drainage must be adequate, irrigation water must be in excess to provide considerable leaching and salt tolerant crops should be selected.
Classification of irrigation waters with respect to SAR is based primarily on the effect of exchangeable sodium on the physical condition of the soil.

The sodium absorption ratio (SAR) was calculated by the following equation given by Richards 1954 as follows:

$\mathrm{SAR}=\frac{\mathrm{Na}^{+}}{\sqrt{\left(\frac{\left(\mathrm{Ca}^{2+}+\mathrm{Mg}^{2+}\right)}{2}\right)}}$

where ion concentrations are expressed in meq/L. The USSL diagram based on SAR is divided into four categories as follows:

(1) Low sodium water $\left(S_{1}\right)$ can be used for irrigation on almost all soils.

(2) Medium sodium water $\left(\mathrm{S}_{2}\right)$ in fine-textured soils of high cation exchange capacity, especially under low leaching conditions, unless gypsum is present in the soil. This water may be used on coarse-textured or organic soils which have good permeability

(3) High sodium water $\left(\mathrm{S}_{3}\right)$ may produce harmful levels of exchangeable sodium in most soil and will require special soil management.

(4) Very high sodium water $\left(\mathrm{S}_{4}\right)$ is generally unsatisfactory for irrigation purposes unless special action is taken such as addition of gypsum to soil.

\section{Mixing models}

Water formed by the mixing of geothermal water with cold ground or surface water possesses many chemical characteristics which serve to distinguish it from unmixed geothermal water. The reason is that the chemistry of geothermal water is characterized by equilibrium conditions between solutes and alteration minerals at relatively high temperatures, whereas the composition of cold water appears to be mostly determined by the kinetics of the leaching process (Arnórsson 1985). Geothermal water, which ascends from a reservoir and emerges at the surface in hot springs, may cool by conduction, mixing with colder water or a combination of these processes. In addition, complete or partial chemical re-equilibration may occur as temperature decreases. The effect of mixing of geothermal water and cold water can be explained with the help of Giggenbach triangular diagram and Schoeller diagram

\section{Giggenbach triangular diagram (Giggenbach 1988)}

Giggenbach (1988) combined the fast responding $\mathrm{K}-\mathrm{Mg}$ geothermometer with the slowly re-equilibrating $\mathrm{Na}-\mathrm{K}$ geothermometer by means of triangular plot. It is an excellent method to assess the degree of attainment of water-rock equilibrium. 
Geothermometers are subsurface temperature indicators derived from temperature-dependent geochemical and isotopic composition of hot spring water. Na-K geothermometer shows always deep equilibria (usually with the highest temperature) and $\mathrm{K}-\mathrm{Mg}$ relates to shallower equilibration (usually with the lowest temperature). This method only describes equilibrium processes at different levels and upflow rates in a thermal reservoir.

The Na-K-Mg triangle defines the equilibrium state of waters using the relationship between $\mathrm{Na} / 1000, \mathrm{~K} / 100$ and $\mathrm{Mg}^{1 / 2}$. Giggenbach triangle is composed of three main zones such as immature water (dissolution of rocks is not followed by equilibration) along the base, partially equilibrated (some extent of equilibration) water in the middle and fully equilibrated (water compositions in equilibrium with the mineral phases) water along the upper curve. The extent of rock-water equilibrium can be determined from the sample plots on the triangle that depends on the concentration of potassium $\left(\mathrm{K}^{+}\right)$, magnesium $\left(\mathrm{Mg}^{2+}\right)$ and sodium $\left(\mathrm{Na}^{+}\right)$.

\section{Schoeller diagram (Schoeller 1964)}

The Schoeller diagram compares the concentration of constituents from a number of analyses and constituents of each analysis connected with a line. The diagram shows the total concentration of major ions in semi-log scale. The effect of mixing with dilute water (as well as gain or loss of steam) is to move the line representing an analysis vertically without changing its shape. Slopes of lines between constituents represent concentration ratios. If the waters have different concentrations, they will appear on the graph one above the other, thus indicating relative movement of the groundwater between the points of origin of these analyses; the flow being from lower concentration to higher concentration. These diagrams show the effect of mixing of a number of constituents. The groundwater samples are grouped into two, and the median concentrations of their anions $\left(\mathrm{SO}_{4}{ }^{2-}, \mathrm{HCO}_{3}{ }^{-}, \mathrm{Cl}^{-}\right)$and cations $\left(\mathrm{Mg}^{2+}, \mathrm{Ca}^{2+}, \mathrm{Na}^{+}\right)$are plotted on the Schoeller diagram. Examination of the Schoeller diagram shows similar slope of lines connecting solute concentrations. This is an indication of groundwater from a similar source. Crossing lines on the diagram represent water types of unrelated origin. It is effective in showing this mixing and serves as an indicator of the water chemistry of the study area.

\section{Results and discussion}

\section{Major ion chemistry of groundwater}

\section{Drinking suitability}

The collected groundwater samples of the study area showed room temperature and ranged between 16.8 and $24.5^{\circ} \mathrm{C}$. This means that groundwater in the study area has not been affected by geothermal heat which is insignificant at those depths. The turbidity of all the sampling sites $\left(\mathrm{S}_{1}\right.$ to $\left.\mathrm{S}_{18}\right)$ except the Middle street $\left(\mathrm{S}_{5}\right)$ was within the limit of 5.0 NTU. The sampling site $S_{5}$ was found to be more turbid which indicates more discharging waste and algal growth. Electrical conductance is a direct function of its total dissolved salts. Hence, it is an index to represent the total concentration of soluble salts in water. The conductance varied between 679 and $3132 \mu \mathrm{mhos} / \mathrm{cm}$. Very high conductance was observed in $\mathrm{S}_{5}(3132 \mu \mathrm{mhos} / \mathrm{cm})$ that reflects the pollution status of aquatic body. It may be due to the long residence time and factors of lithology of water bodies. The sampling sites in the study area showed the TDS at $S_{13}(462 \mathrm{mg} / \mathrm{L})$ and $S_{18}(500 \mathrm{mg} / \mathrm{L})$ falls within the limit of $500 \mathrm{mg} / \mathrm{L}$. Very high level of TDS at Middle street $(2130 \mathrm{mg} / \mathrm{L})$ indicates high concentration of dissolved ions, which render water non-potable, corrosive and of salty or brackish taste. High concentrations of TDS in groundwater affect persons who are suffering from kidney and heart diseases.

ISI (1991) and WHO (1988) prescribed the desirable range of $\mathrm{pH}$ in water for drinking purpose is between 6.5 and 8.5. The $\mathrm{pH}$ of water samples is ranged from 6.87 to 8.11 , and it is found to be well within the limits. Total hardness is due to the presence of bicarbonates, sulfates and chlorides of calcium and magnesium. The desirable limit is $300 \mathrm{mg} / \mathrm{L}$, and the maximum permissible limit for drinking water is $600 \mathrm{mg} / \mathrm{L}$ as per Indian standards. The sampling sites in the study area such as Usilampatti road $\left(S_{3}\right)$, Middle Street $\left(S_{5}\right)$ and M.Vadipatti $\left(S_{9}\right)$ exceeds the permissible limit indicates the percolation of sewage effluents into groundwater. Other sampling sites in the study area fall within the permissible limit. Hujare (2008) reported total hardness was high during summer than rainy and winter season. High value of hardness during summer can be attributed to decrease in water volume and increase in rate of evaporation of water. The desirable limit of alkalinity was observed at the sampling sites Bodikamanvadi $\left(\mathrm{S}_{11}\right)$, Boystown $\left(\mathrm{S}_{13}\right)$ and Devathanapatty $\left(\mathrm{S}_{17}\right)$. On the other hand, alkalinity of the other 15 sampling sites exceeds the desirable limit. Beyond the permissible limit, alkalinity causes many problems like kidney stone, gas trouble, severe eye irritation, skin and mucus membrane. 
(Bangash and Alam 2004). Very high concentration of calcium and magnesium is observed at the sampling sites Usilampatti road $\left(\mathrm{S}_{3}\right)$, Middle Street $\left(\mathrm{S}_{5}\right)$ and M.Vadipatti $\left(S_{9}\right)$ which reflected the concentration of total hardness in the same sampling sites. Other sampling sites except Mallanampatti $\left(\mathrm{S}_{2}\right)$ and Anna Nagar $\left(\mathrm{S}_{4}\right)$ are within the desirable limit due to the dilution effect on rainwater. The greatest source of chloride in fresh water is disposal of sewage and industrial wastes. Very high concentration of chloride is observed at Middle street $\left(\mathrm{S}_{5}\right)$ and M.Vadipatti $\left(\mathrm{S}_{9}\right)$ which might be the dissolution of organic waste due to discharge of industrial effluents and domestic sewage. Other sampling sites showed within the desirable limit $(<250 \mathrm{mg} / \mathrm{L})$. Marechal et al. (2006) reported higher chloride concentration in groundwater due to sewage water. The sulfate concentration in the study area varied between 25 and $150 \mathrm{mg} / \mathrm{L}$ due to the discharge of effluent and fertilizers. Elevated level of sulfate causes gastrointestinal irritation when magnesium and sodium are present. Nitrate is the most important nutrient in an ecosystem. Nitrates are generally found in water due to bacterial action of ammonia and organic nitrogen. When water with high nitrogen concentration is used for drinking, it causes diseases like methaemoglobinaenia. Nitrate concentration varied from 5 to $20 \mathrm{mg} / \mathrm{L}$ for the sampling sites $S_{1}$ to $S_{18}$. The concentration of nitrite varied from 0.11 to $0.38 \mathrm{mg} / \mathrm{L}$, and ammonia is varied between 0.18 and $0.86 \mathrm{mg} / \mathrm{L}$.

Fluoride is a double-edged sword. Low concentration of fluoride below $0.5 \mathrm{mg} / \mathrm{L}$ causes dental caries and higher concentration beyond $1.5 \mathrm{mg} / \mathrm{L}$ causes dental and skeletal fluorosis. The concentration of fluoride at all the sampling sites observed within the desirable limit except the sites $S_{2}$ (2.0) and $S_{12}$ (1.2). Very high concentration of fluoride at Mallanampatti $\left(\mathrm{S}_{2}\right)$ may lead to dental and skeletal fluorosis. According to WHO guideline, the concentration of sodium in drinking water is $200 \mathrm{mg} / \mathrm{L}$. The sampling sites such as Mallanampatti $\left(\mathrm{S}_{2}\right)$, Anna Nagar $\left(\mathrm{S}_{4}\right)$, Middle Street $\left(\mathrm{S}_{5}\right)$, Periyakulam road $\left(S_{6}\right)$, Vegetable Market $\left(S_{7}\right)$, M.Vadipatti $\left(\mathrm{S}_{9}\right)$, Bodikamanvadi $\left(\mathrm{S}_{11}\right)$ and Temple $\left(\mathrm{S}_{16}\right)$ showed high concentration of sodium due to high rate of mineralization of the sediments. Studies have shown that reduced salt intake will lower blood pressure in people with hypertension, but cannot be conclusively inferred that increased sodium intake will cause hypertension (Radojevic and Bashkin 1999). The highest amount of sodium and chloride at those sampling sites made the water sour. But other sampling sites fall within the limit of $200 \mathrm{mg} / \mathrm{L}$. Low concentration of potassium is observed at Usilampatti road $\left(\mathrm{S}_{3}\right)$ and high at Middle Street $\left(\mathrm{S}_{5}\right)$. Though potassium is extensively found in some of igneous and sedimentary rocks, its concentration in natural waters is usually quite low. This is due to the fact that potassium minerals offer resistance to weathering and dissolution. The high levels of both phosphates and nitrates can lead to eutrophication, which increases algal growth and ultimately reduces dissolved oxygen in the water. The presence of phosphates in groundwater may be attributed to natural minerals or through pollution by application of fertilizer, sewage and industrial waste (Alemu et al. 2015). The concentration of phosphate for the collected sampling sites is in the range of $0.23-1.0 \mathrm{mg} / \mathrm{L}$ which falls within the prescribed limit of WHO standards.

Dissolved oxygen is one of the most important parameters in assessing the water quality and reflects the physical and biological process prevailing in the water. In the study area, DO fluctuates between 5.0 and $8.1 \mathrm{mg} / \mathrm{L}$. The minimum DO recorded at Coir industry $\left(\mathrm{S}_{8}\right)$ is due to mixing of the chemical effluents. The decrease in DO of water is due to its poor ability to hold oxygen at high temperature as a result of higher rate of microbial metabolism (Lewis 2000). The maximum DO at Salaipudur $\left(\mathrm{S}_{10}\right)$ may therefore be considered as negligibly polluted and is suitable for most of the beneficial uses such as drinking and irrigation. The maximum BOD acceptable limit is $5 \mathrm{mg} / \mathrm{L}$ according to WHO. The source of BOD is mainly due to the discharge of untreated effluent from industries. BOD concentration at all the 18 sampling sites showed within the limit of $5 \mathrm{mg} / \mathrm{L}$. Water with low BOD has low nutrient levels, and this implies high concentration of dissolved oxygen. COD is an index of the total organic content of water demanding substance in water. It means the amount of oxygen required for oxidation of oxidizable organic matter. High levels of biochemical oxygen demand and chemical oxygen demand indicate depletion of the dissolved oxygen in the water systems. (Jayalakshmi 2011). According to WHO, the desirable limit of COD is $20 \mathrm{mg} / \mathrm{L}$. The concentration at all the 18 sampling sites showed within the limit of WHO standards.

\section{Correlation analysis of physicochemical parameters of groundwater}

The correlation analysis between physicochemical parameters is studied for the 18 sampling sites of Batlagundu in Dindigul district. This correlation coefficient measures the degree of association or correlation that exists between the two variables. The correlation matrix for different groundwater quality variables is depicted in Table 4 . The electrical conductance (EC) shows the significant correlation with most of the physicochemical parameters studied. In this study area, it is evident that distribution of total dissolved solids (TDS) $(r=+1.00)$, total hardness (TH) $(r=+0.795)$, calcium (Ca) $(r=+0.768)$, magnesium $(\mathrm{Mg})(r=+0.823)$, sodium $(\mathrm{Na})(r=+0.944)$, potassium $(\mathrm{K})(r=+0.817)$, ammonia $\left(\mathrm{NH}_{3}\right)(r=+0.540)$, chloride $(\mathrm{Cl})(r=+0.992)$, sulfate $\left(\mathrm{SO}_{4}\right)(r=+0.830)$ and phosphate $\left(\mathrm{PO}_{4}\right)(r=+0.595)$ were significantly correlated with electrical conductance in most of the sampling sites. In the study area, the highest 


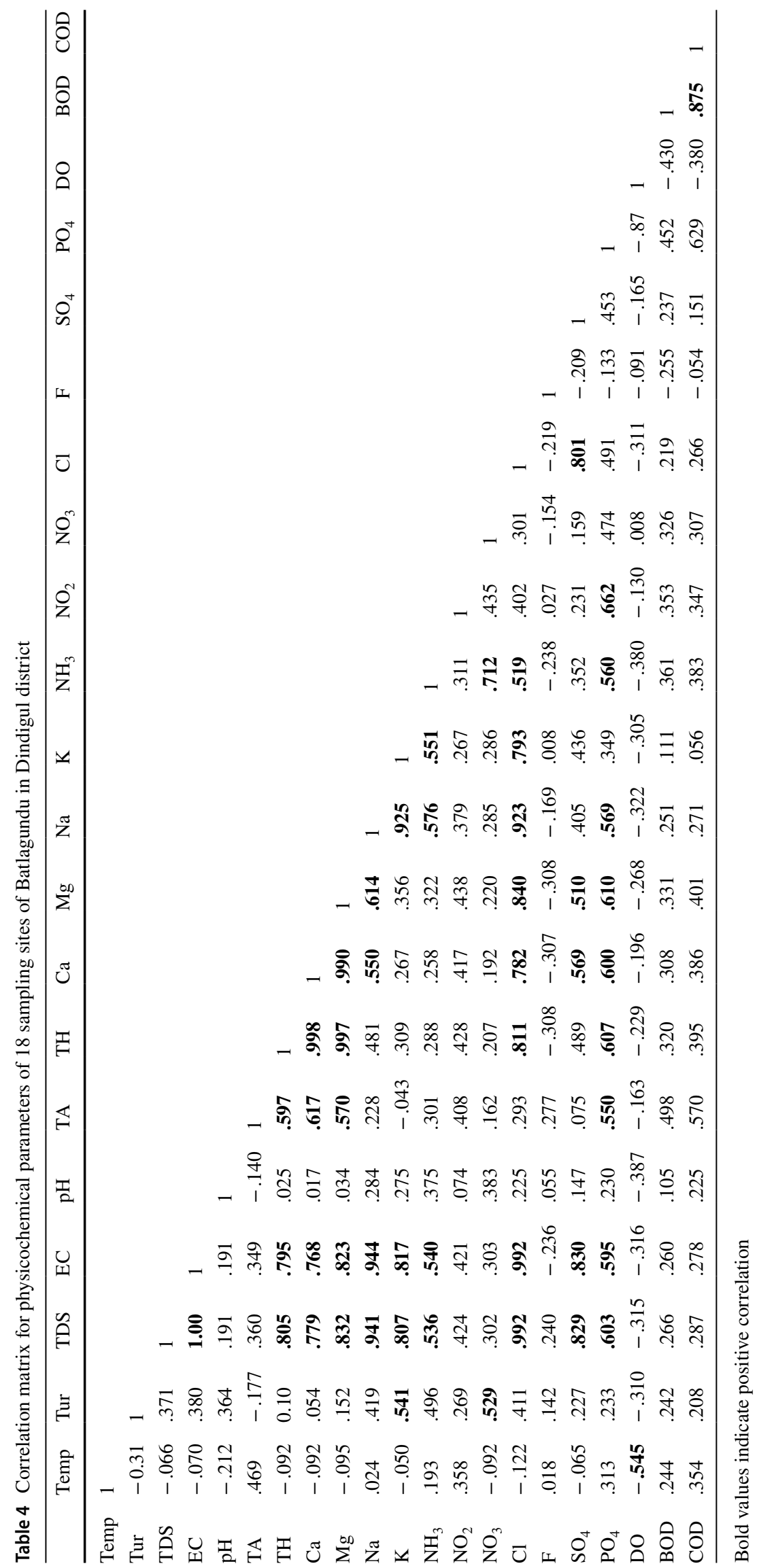


positive correlation is observed between electrical conductance and total dissolved solids (EC-TDS) $(r=+1.00)$. Findings of the present study were in agreement with the results of the survey conducted by Samina et al. (2004) and Jain et al. (2005) in their studies. It is found that electrical conductance is correlated well with most of the parameters at all the sampling sites in the study area. Therefore, the quality of groundwater can be predicted with sufficient accuracy just by the measurement of EC alone. This provides a mean for easier and faster monitoring of water quality in all location.

Total hardness showed significant positive correlation $(r>0.8)$ with calcium, magnesium and chloride. Sulfate is also correlated with $\mathrm{Ca}(r=+0.569), \mathrm{Mg}(r=+0.51)$ and $\mathrm{Cl}$ $(r=+0.801)$. It is found that total hardness of water sample is mainly due to the presence of chlorides and sulfates of calcium and magnesium. Alkalinity showed positive correlation with $\mathrm{TH}, \mathrm{Ca}$ and $\mathrm{Mg}$. The results are in agreement with the findings of Devi et al. (2003). The significant correlation shown between nitrate and phosphate $(r=+0.57)$ is associated with the use of fertilizers and pesticides in agricultural activities. It is observed that dissolved oxygen (DO) has a negative correlation with temperature at all the sampling sites in the study area. The inverse relationship between temperature and DO is a natural process as warmer water becomes more easily saturated with oxygen and holds less. A good correlation between BOD-COD relationship for polluted water estimated by regression equation agrees well with the measured relationship.

The significance of the relationship is also highly supported by $F$ values. The values of variance ratio $F$ are high and standard error of the estimate $S$ is low and these are also necessary requirements for significant correlation. Different pairs of water quality parameters with significant correlation coefficient $(r>0.9)$, variance ratio $(F)$ and standard error of the estimate $(S)$ are given in Table 5.

Table 5 Correlation coefficient for significant water quality parameters, variance ratio $(F)$ and standard error of the estimate $(S)$

\begin{tabular}{llcl}
\hline Matrix pair & $\begin{array}{l}\text { Correlation } \\
\text { coefficient value } \\
(r)\end{array}$ & Variance ratio $(F)$ & $\begin{array}{l}\text { Standard error of } \\
\text { the estimate }(S)\end{array}$ \\
\hline EC-TDS & 1.00 & $39,428.878$ & $15.73,594$ \\
$\mathrm{TH}-\mathrm{Ca}$ & 0.998 & 3604.307 & 13.45096 \\
$\mathrm{TH}-\mathrm{Mg}$ & 0.997 & 2562.590 & 15.93804 \\
$\mathrm{Na}-\mathrm{TDS}$ & 0.941 & 124.481 & 32.51889 \\
$\mathrm{Na}-\mathrm{EC}$ & 0.944 & 132.00 & 31.68208 \\
$\mathrm{Na}-\mathrm{K}$ & 0.925 & 95.018 & 36.58034 \\
$\mathrm{Na}-\mathrm{Cl}$ & 0.923 & 92.460 & 37.00920 \\
$\mathrm{Na}-\mathrm{SO}$ & 0.905 & 72.449 & 40.98237 \\
$\mathrm{Cl}-\mathrm{TDS}$ & 0.992 & 1192.018 & 15.897 \\
$\mathrm{Cl}-\mathrm{EC}$ & 0.992 & 1191.567 & 16.389 \\
\hline
\end{tabular}

\section{Hydrochemical facies diagram}

\section{Piper trilinear diagram}

The hydrofacies analysis of water in the study area can be understood by plotting the major cations and anions in the Piper trilinear diagram. Three well-defined fields are depicted in the diagram consisting of two triangular and a central diamond-shaped field representing the overall characteristics of water (Oki and Akana 2016). The geochemical evolution can be described from the Piper plot (Piper 1953) which has been divided into six subcategories such as I (Ca- $\mathrm{HCO}_{3}$ type), II (Na-Cl type), III (mixed $\mathrm{Ca}-\mathrm{Na}-$ $\mathrm{HCO}_{3}$ type), IV (mixed $\mathrm{Ca}-\mathrm{Mg}-\mathrm{Cl}$ type), $\mathrm{V}$ (Ca-Cl type) and VI (Na-HCO ${ }_{3}$ type). Samples in the field of category I are characterized as temporary hardness of water, category II as saline water, category III and IV results from mineral dissolution or mixing of two chemically distinct groundwater bodies, category $\mathrm{V}$ as permanent hardness and category $\mathrm{VI}$ as alkali carbonate.

The Piper diagram (Fig. 2) of Batlagundu block in Dindigul district for the sampling sites $S_{1}$ to $S_{18}$ showed that the

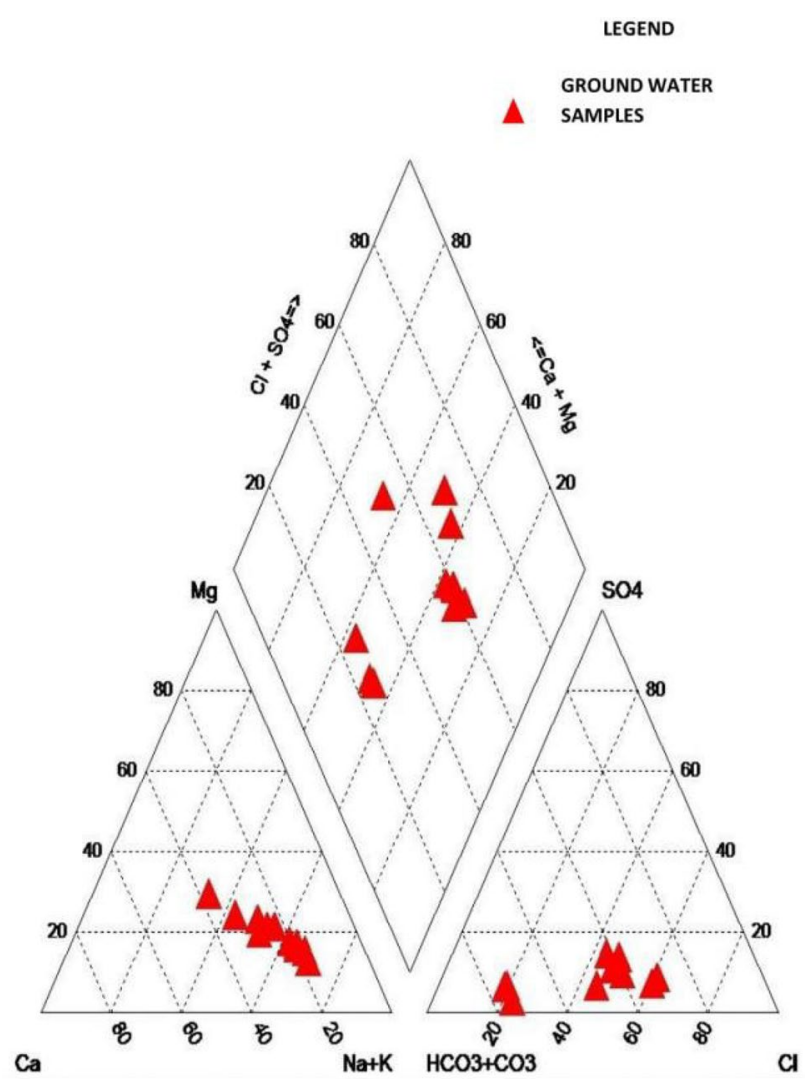

Fig. 2 Piper trilinear diagram of 18 groundwater samples of Batlagundu block in Dindigul district 
groundwater samples are plotted in the field of $\mathrm{Ca}-\mathrm{HCO}_{3}$ type (Category I), Na-Cl type (Category II), mixed $\mathrm{Ca}-\mathrm{Na}-\mathrm{HCO}_{3}$ (Category III) and mixed $\mathrm{Ca}-\mathrm{Mg}-\mathrm{Cl}$ type (Category IV) of water. In the study area, calcium $\left(\mathrm{Ca}^{2+}\right)$ and magnesium $\left(\mathrm{Mg}^{2+}\right)$ are found to be very common in the groundwater. This is due to the presence of calcic plagioclase feldspar in the alluvium, and it is derived from surrounding basic igneous rocks. The concentration of calcium varied between 42 and $200 \mathrm{mg} / \mathrm{L}$ and magnesium ranged from 21 to $96 \mathrm{mg} / \mathrm{L}$. The abundance of $\mathrm{Ca}^{2+}$ and $\mathrm{Mg}^{2+}$ in the groundwater could be related to the presence of carbonate rocks in the study area. The alkalinity of water is the measure of its capacity for neutralization which is represented by bicarbonate $\left(\mathrm{HCO}_{3}{ }^{-}\right) . \mathrm{HCO}_{3}{ }^{-}$was the dominant anion in the study area which varied from a minimum of $219.6 \mathrm{mg} / \mathrm{L}$ to a maximum of $485.6 \mathrm{mg} / \mathrm{L}$. Dissolution is a simple and common weathering reaction in carbonate rocks. Naturally, this could be represented by the following reactions:

$\mathrm{CaMg}\left(\mathrm{CO}_{3}\right)_{2}+\mathrm{H}_{2} \mathrm{CO}_{3} \rightarrow \mathrm{Ca}^{2+}+\mathrm{Mg}^{2+}+4 \mathrm{HCO}_{3}^{-}$

\section{Dolomite}

Identification of $\mathrm{Na}-\mathrm{Cl}$ water type in the study area could be supported by very high concentration of total dissolved solids (462-2130 mg/L) and electrical conductance (679-3132 $\mu \mathrm{mhos} / \mathrm{cm})$. It represents the brackish to saline water type. The high concentration of sodium $\left(\mathrm{Na}^{+}\right)$and chloride $\left(\mathrm{Cl}^{-}\right)$in the study area has originated from various sources such as seawater intrusion, evaporated deposits and fossil saline water entrapped in the sediments.

\section{USSL diagram}

USSL classification of groundwater for the sampling sites $\mathrm{S}_{1}$ to $\mathrm{S}_{18}$ of Batlagundu block in Dindigul district is given in Fig. 3. This diagram classified the samples into $\mathrm{C}_{3} \mathrm{~S}_{1}$ (high salinity and low sodium), $\mathrm{C}_{3} \mathrm{~S}_{2}$ (high salinity and medium sodium) and $\mathrm{C}_{4} \mathrm{~S}_{2}$ (very high salinity and medium sodium) category. The values of EC at the sampling sites $\mathrm{S}_{13}(679 \mu \mathrm{mhos} / \mathrm{cm})$ and $\mathrm{S}_{18}(736 \mu \mathrm{mhos} / \mathrm{cm})$ lie between 250 and $750 \mu \mathrm{mhos} / \mathrm{cm}$. SAR values at $S_{13}(1.22 \mathrm{meq} / \mathrm{L})$ and $S_{18}(1.35 \mathrm{meq} / \mathrm{L})$ showed less than $10 \mathrm{meq} / \mathrm{L}$. It indicated that the water samples from the above-said sampling sites are suitable for irrigation.

All the sampling sites of Batlagundu block in Dindigul district except Middle street $\left(\mathrm{S}_{5}\right)$ and M.Vadipatti $\left(\mathrm{S}_{9}\right)$
Fig. 3 USSL diagram of 18 groundwater samples of Batlagundu block in Dindigul district. SAR Sodium HazardS1: Low S2:Medium S3: High S4: Very high, Cond Salinity Hazard-C1: Low C2: Medium C3: High C4: Very high

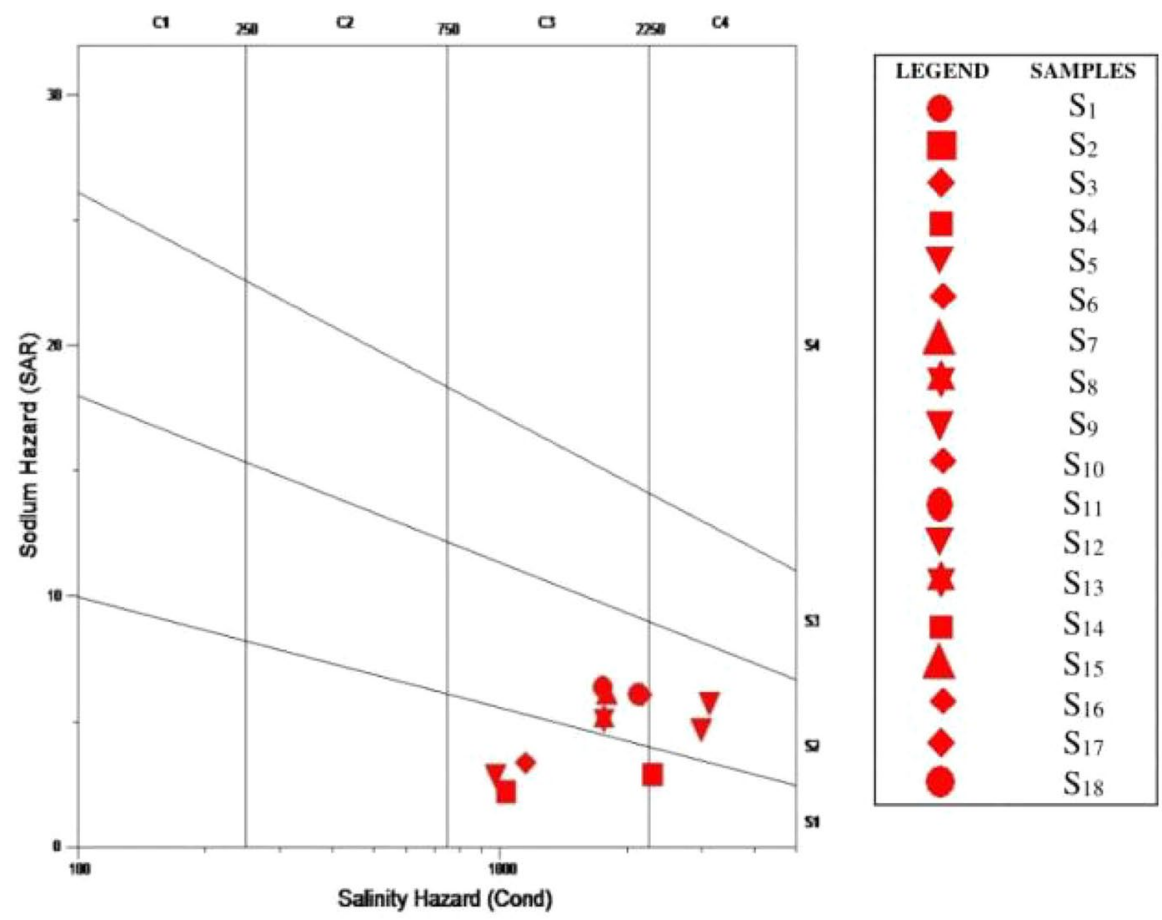

Sodium Hazard (SAR) - S1-Low S2-Medium S3-High S4-Very high

Salinity Hazard (Cond) - C1-Low C2-Medium C3-High C4-Very high 
Table 6 Classification of sodium hazard based on SAR and salinity hazard based on EC

\begin{tabular}{|c|c|c|c|c|c|c|}
\hline \multirow[t]{2}{*}{ S. no } & \multicolumn{3}{|c|}{ Sodium hazard (USSL 1954) } & \multicolumn{3}{|c|}{ Salinity hazard (Rao 2005) } \\
\hline & $\begin{array}{l}\text { Sodium haz- } \\
\text { ard class }\end{array}$ & $\begin{array}{l}\text { Sodium absorp- } \\
\text { tion ratio (SAR) }\end{array}$ & $\begin{array}{l}\text { Remark on } \\
\text { water quality }\end{array}$ & $\begin{array}{l}\text { Salinity } \\
\text { hazard }\end{array}$ & $\begin{array}{l}\text { Electrical con- } \\
\text { ductance (EC) }\end{array}$ & $\begin{array}{l}\text { Remark } \\
\text { on water } \\
\text { quality }\end{array}$ \\
\hline 1 & $\mathrm{~S}_{1}$ & $<10$ & Low & $\mathrm{C}_{1}$ & $<250$ & Low \\
\hline 2 & $\mathrm{~S}_{2}$ & $10-18$ & Medium & $\mathrm{C}_{2}$ & $250-750$ & Medium \\
\hline 3 & $\mathrm{~S}_{3}$ & $19-26$ & High & $\mathrm{C}_{3}$ & $750-2250$ & High \\
\hline 4 & $\mathrm{~S}_{4}$ & $>26$ & Very high & $\mathrm{C}_{4}$ & $>2250$ & Very high \\
\hline
\end{tabular}

are in the field of $\mathrm{C}_{3} \mathrm{~S}_{1}$ and $\mathrm{C}_{3} \mathrm{~S}_{2}$ category. High salinity and low-to-medium sodium hazard at these sampling sites showed that the water samples are poorly suitable for usual agropurposes, but can be used for cultivating saline resistant crops like barley, palm and cotton (Kumar et al. 2007). Soils affected by high salinity and sodium hazards require gypsum and lime treatment to improve permeability of the soil. Classification of irrigation water based on EC and SAR is given in Table 6.

The groundwater samples at the sampling sites such as Middle street $\left(\mathrm{S}_{5}\right)$ and M.Vadipatti $\left(\mathrm{S}_{9}\right)$ are classified as $\mathrm{C}_{4} \mathrm{~S}_{2}$ category. It indicated that water with very high salinity and medium sodicity cannot be used on fine-grained soils with restricted drainage (Srinivasamoorthy et al. 2012).

\section{Hydrochemical characteristics of the geothermal fluids}

The effect of mixing of geothermal water and cold water can be explained with the help of Giggenbach triangular diagram and Schoeller diagram.

\section{Giggenbach triangle diagram}

The Na-K-Mg triangular diagram (Fig. 4) for the sampling sites $S_{1}$ to $S_{18}$ of Batlagundu block in Dindigul district is useful to recognize the common origin of geothermal fluids. Cold waters usually belong to the immature water group. Cold waters show outlet temperature ranging between 10.1 and $21.4{ }^{\circ} \mathrm{C}$, salinity (expressed as total dissolved solids) between 0.1 and $22 \mathrm{~g} / \mathrm{L}$ and $\mathrm{pH}$ between 6.29 and 8.20. Cold water in the study area is driven by different geochemical processes which includes water-rock interaction and dissolution of gases of different origins occurring during the hydrological paths, which affect the final water characteristics. In this $\mathrm{Na}-\mathrm{K}-\mathrm{Mg}$ diagram, the samples have not gained equilibrium with their host rock, presumably due to fact circulation of fluid through the rock features. This causes the water to be immature equilibrium indicating very high proportion of relatively cold groundwater mixed in the water system. The shifting of data points toward $\mathrm{Mg}^{1 / 2}$ vertex indicates the mixing of deep immature thermal waters with shallow cold water.

Fig. 4 Giggenbach triangle diagram of 18 groundwater samples of Batlagundu block in Dindigul district

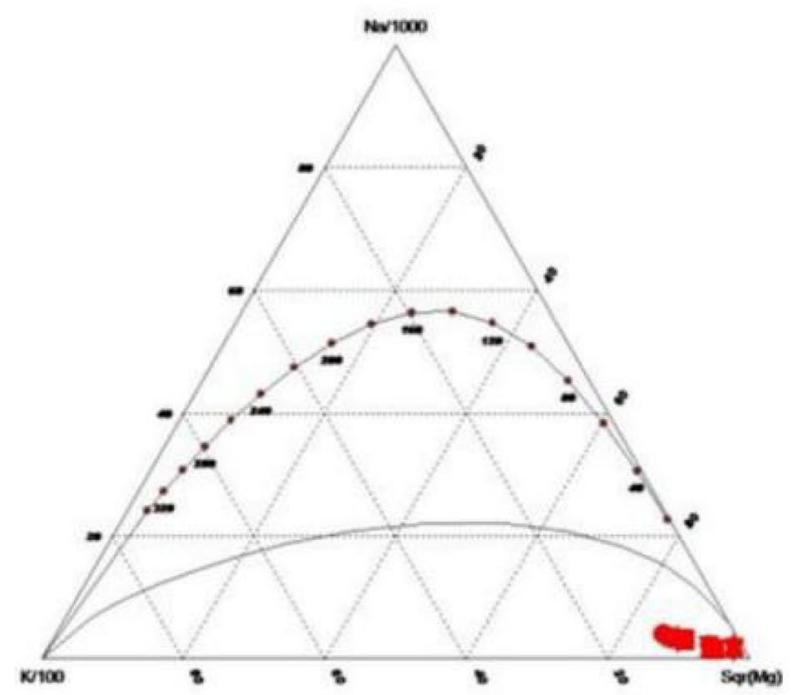

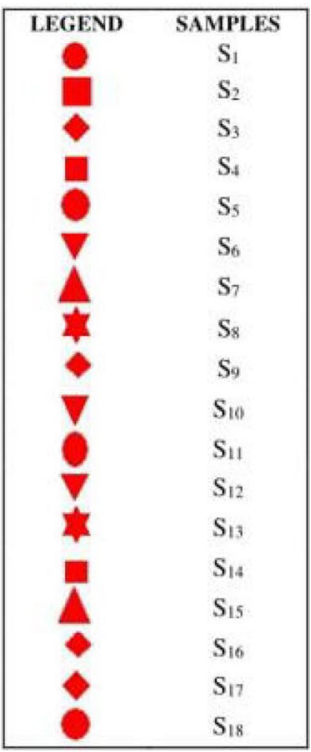


LEGEND

GROUND WATER SAMPLES

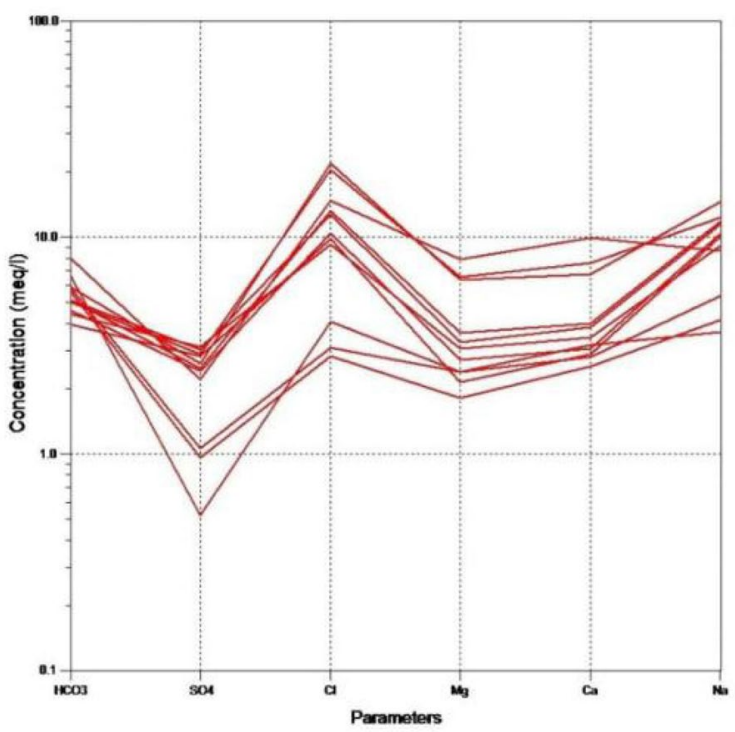

Fig. 5 Schoeller diagram of 18 groundwater samples of Batlagundu block in Dindigul district

\section{Schoeller diagram}

The geochemistry of groundwater in Batlagundu block of Dindigul district for the sampling sites $S_{1}$ to $S_{18}$ is discussed by means of major ions. The Schoeller diagram of the study area is shown in the order of cations $\mathrm{Ca}^{2+}=\mathrm{Mg}^{2+}>\mathrm{Na}^{+}$and anions $\mathrm{HCO}_{3}{ }^{-}>\mathrm{Cl}^{-}>\mathrm{SO}_{4}{ }^{2-}$. From the diagram (Fig. 5), alkaline earths $\left(\mathrm{Ca}^{2+}\right.$ and $\left.\mathrm{Mg}^{2+}\right)$ significantly exceed the alkalis $\left(\mathrm{Na}^{+}\right.$ and $\left.\mathrm{K}^{+}\right)$, while acids of $\left(\mathrm{Cl}^{-}\right.$and $\left.\mathrm{HCO}_{3}{ }^{-}\right)$exceed the acids of $\left(\mathrm{SO}_{4}{ }^{2-}\right.$ and $\left.\mathrm{CO}_{3}{ }^{2-}\right)$. Therefore, the chemical compositions of these classes were characterized by the $\mathrm{Ca}-\mathrm{Mg}-\mathrm{HCO}_{3}$ water type and $\mathrm{Na}-\mathrm{Cl}$ type. This observation is also confirmed with Piper trilinear diagram (Fig. 2) of the study area. Bicarbonates of calcium and magnesium in the study area are due to the carbonate dissolution process and wide contact with limestone. The groundwater samples were classified as $\mathrm{Na}-\mathrm{Cl}$ type, which could be supported by high concentration of total dissolved solids in the groundwater of the study area.

\section{Conclusion}

The hydrochemical analysis of the study area reveals that the groundwater is highly contaminated in Middle street $\left(\mathrm{S}_{5}\right)$ of Batlagundu block in Dindigul district. Seven physicochemical parameters such as turbidity (6.0 NTU), total dissolved solids $(2130 \mathrm{mg} / \mathrm{L})$, electrical conductance $(3132 \mu \mathrm{mhos} / \mathrm{cm})$, chloride $(780 \mathrm{mg} / \mathrm{L})$, nitrite $(0.38 \mathrm{mg} / \mathrm{L})$, sodium $(336 \mathrm{mg} / \mathrm{L})$ and ammonia $(0.86 \mathrm{mg} / \mathrm{L})$ were found to exceed BIS desirable limits. The high contamination of this residential area is significantly affected by precipitation. It leads to infiltration of water that carries pollutants from anthropogenic sources and dissolved salts from the geological strata that the water passes through. The remaining sampling sites were within the range of WHO (2004) and BIS (1999) limits. Correlation analysis showed that electrical conductance was well correlated with most of the parameters studied. It is proved that electrical conductance is an important water quality parameter. Therefore, it is easy to predict the water quality by making observation on electrical conductance alone. The Piper trilinear diagram and Schoeller diagram of the study area are shown in the order of cations $\mathrm{Ca}^{2+}=\mathrm{Mg}^{2+}>\mathrm{Na}^{+}$and anions $\mathrm{HCO}_{3}{ }^{-}>\mathrm{Cl}^{-}>\mathrm{SO}_{4}{ }^{2-}$. Therefore, the chemical compositions of water samples were characterized by the $\mathrm{Ca}-\mathrm{Mg}-\mathrm{HCO}_{3}$ water type and $\mathrm{Na}-\mathrm{Cl}$ type. The sources of calcium $\left(\mathrm{Ca}^{2+}\right)$ and sodium $\left(\mathrm{Na}^{+}\right)$in the groundwater are from the minerals like silicates, feldspars, pyroxenes and amphiboles identified in the rocks types of the study area. The source of bicarbonate in the study area is due to the weathering of silicate minerals and oxidation of organic matter that promotes dissolution of minerals. USSL diagram of the groundwater samples such as Middle street $\left(\mathrm{S}_{5}\right)$ and M.Vadipatti $\left(\mathrm{S}_{9}\right)$ is classified as $\mathrm{C}_{4} \mathrm{~S}_{2}$ category. It revealed that the water samples are unfit for irrigation. The shifting of data points toward $\mathrm{Mg}^{1 / 2}$ vertex in Giggenbach triangular diagram indicates the mixing of deep immature thermal waters with shallow cold water. The findings obtained from the assessment have shown that the groundwater of Batlagundu block in Dindigul district is unreliable for drinking water supply and domestic purposes.

Open Access This article is distributed under the terms of the Creative Commons Attribution 4.0 International License (http://creativeco mmons.org/licenses/by/4.0/), which permits unrestricted use, distribution, and reproduction in any medium, provided you give appropriate credit to the original author(s) and the source, provide a link to the Creative Commons license, and indicate if changes were made.

\section{References}

Alemu ZA, Teklu KT, Alemayehu TA, Balcha KH, Mengesha SD (2015) Physicochemical quality of drinking water sources in Ethiopia and its health impact: a retrospective study. Environ Syst Res 4:22

Anku YS, Banoeng Yakubo B, Asiedu DK, Asiedu SM (2009) Water quality analysis of groundwater in crystalline basement rocks, northern Ghana. Environ Geol 58:989-997

APHA, AWWA, WPCF (2005) Standard methods for the examination of waters and waste waters, 21st edn. American Public Health Association (APHA), Washington

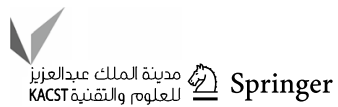


Arnórsson S (1985) The use of mixing models and chemical geothermometers for estimating underground temperature in geothermal systems. J Volcanol Geotherm Res 23:299-335

Ayibatatele NB (1992) First seosun environmerita baseline survey. Proc Int Conf Water Environ 1:4-26

Bangash FK, Alam S (2004) Extent of pollutants in the effluents of Hayatabad Industrial Estate, Peshawar. J Chem Soc Pak 26(3):271-278

BIS, Bureau of Indian Standards (1999) Indian standard drinking water specification

Chopra RPS, Krishan G (2014) Assessment of groundwater quality in Punjab, India. Earth Sci Clim Change 5:10

Devi S, Varbuddhe SB, Hazel D, Dolly C (2003) Physico-chemical characteristics of drinking water at Velsao, Goa. Ecotoxicol Environ Monit 13(3):203-209

Giggenbach WF (1988) Geothermal solute equilibria. Derivation of $\mathrm{Na}-\mathrm{K}-\mathrm{Mg}-\mathrm{Ca}$ geoindicators. Geochim et Cosmochimica Acta 52:2749-2765

Goel PK (2000) Water pollution-cause, effects and control. New Age Inter (P) Ltd., New Delhi

Gupta S, Mahato A, Roy P, Datta JK, Saha RN (2008) Geochemistry of groundwater, Burdwan district, West Bengal, India. Environ Geol 53:1271-1282

Hujare MS (2008) Seasonal variation of physico-chemical parameters in the perennial tank of Talsande, Maharashtra. Ecotoxicol Environ Monit 18(3):233-242

Irfan M, Said M (2008) Hydrochemical characteristics and the effects of irrigation on groundwater quality in Harran Plain, GAP Project, Turkey. Environ Geol 54:183-196

ISI, Indian Standard Institute (1991) Indian standard for drinking water as per BIS specifications (IS 10500-1991)

Jain CK, Omkar, Sharma MK (1996) Ground water quality monitoring and evaluation in and around Kakinada, Andra Pradesh, technical report, CS (AR) 172. National Institute of Hydrology, Roorkee 1994-1995

Jain P, Sharma JD, Sohu D, Sharma P (2005) Chemical analysis of drinking water of villages of sanganer Tehsil, Jaipur district. Int J Environ Sci Technol 2(4):373-379

Jamshidzadeh Z, Mirbagheri SA (2011) Evaluation of groundwater quantity and quality in the kashan Basin Central Iran. Desalination 270:23-30

Jayalakshmi V (2011) Assessment of physico-chemical parameters of water and waste waters in and around Vijayawada. Int J Res Pharm Biomed Sci 2(3):1041-1046

Jayasena HAH, Chandrajith R, Dissanayake CB (2008) Hydrogeochemistry of the groundwater flow system in a crystalline terrain: a study from the Kurunegala district, Sri Lanka. Environ Geol 55:723-730

Kannan N, Joseph S (2009) Quality of groundwater in the shallow aquifers of a paddy dominated agricultural river Basin, Kerala, India. World Acad Sci Eng Technol 52:475-493

Kumar M, Kumari K, Ramanathan AL, Saxena R (2007) A comparative evaluation of groundwater suitability for irrigation and drinking purposes in two intensively cultivated districts of Punjab, India. Environ Geol 53:553-574

Kumar M, Kumari K, Singh UK, Ramananthan AL (2009) Hydrogeochemical processes in the groundwater environment of Muktsar, Punjab: conventional graphical and multivariate statistical approach. Environ Geol 57:873-884

Lewis WM (2000) Basis for the protection and management of tropical lakes. Lakes Reserv Res Manag 5:35-48

Marechal JC, Ahmad S, Engerrand C, Galeazzi L, Touchard F (2006) Threatned ground water resources in rural India: an example of monitoring, Asian. J Water Environ Pollut 3(2):15-21

NEERI (1986) Manual on water and waste water analysis. National Environmental Engineering Research Institute, Nagpur
Oki AO, Akana TS (2016) Quality assessment of groundwater in Yenagoa, Niger Delta, Nigeria. Geosciences 6(1):1-12

Omo-Irabor OO, Olobaniyi SB, Oduyemi K, Akunna J (2008) Surface and groundwater water quality assessment using multivariate analytical methods: a case study of the Western Niger Delta, Nigeria. Phys Chem Earth Parts A/B/C 33(8-13):666-673

Piper AM (1944) A graphical procedure in the geochemical interpretation of water analysis. Trans Am Geophys Union 25:914-928

Piper AM (1953) A graphic procedure in the geo-chemical interpretation of water analysis, USGS groundwater note no. 12:63

Prasanna MV, Chidambaram S, Shahul Hameed A, Srinivasamoorthy K (2011) Hydrogeochemical analysis and evaluation of groundwater quality in the Gadilam river basin, Tamil Nadu, India. J Earth Syst Sci 120:85-98

Radojevic M, Bashkin VN (1999) Practical environmental analysis. Royal Society of Chemistry, London

Rao NS (2005) Seasonal variation of groundwater quality in a part of Guntur district, Andhra Pradesh, India. Environ Geol 49:413-429

Richards LA (1954) Diagnosis and improvement of saline and alkali soils. Agriculture handbook 60. U.S. Department of Agriculture, Washington, $\mathrm{p} 160$

Samina J, Jaffar M, Shah MH (2004) Physico-chemical profiling of ground water along Hazara Strip, Pakistan. J Chem Soc Pak 26(3):288-292

Sarala Thambavani D, Uma Mageswari TSR (2013) Metal pollution assessment in ground Water. Bull Environ Pharmacol Life Sci 2(12):122-129

Sarala Thambavani D, Uma Mageswari TSR (2014) Water quality indices as indicators for potable water. Desal Water Treat 52:4772-4782

Schoeller H (1964) La classification geochimique des waux. I.A.S.H. Publication no. 64. Gen Assembly Berkeley 4:16-24

Singh K, Hundal HS, Singh D (2011) Geochemistry and assessment of hydrogeochemical processes in groundwater in the southern part of Bathinda district of Punjab, northwest India. Environ Earth Sci 64:1823-1833

Sonawane VY, Khole AM (2010) Water quality of some drinking waters in Parbhani city: a case study. J Chem Pharm Res 2(5):104-107

Srinivasamoorthy K, Nanthakumar C, Vasanthavigar M, Vijayaraghavan K, Rajivganthi R, Chidambaram S (2009) Groundwater quality assessment from a hard rock terrain, salem district of Tamilnadu, India. Arab J Geosci 4:02-91

Srinivasamoorthy K, Vasanthavigar M, Chidambaram S, Anandhan P, Manivannan R, Rajivgandhi R (2012) Hydrochemistry of groundwater from Sarabanga Minor Basin, Tamil Nadu, India. Proc Int Acad Ecol Environ Sci 2:193-203

Subramani T, Elango L, Damodarasamy SR (2005) Groundwater quality and its suitability for drinking and agricultural use in Chithar River Basin, Tamil Nadu, India. Environ Geol 47:1099-1110

Tamma RG, Srinivasa RY, Mahesh J, Surinaidu L, Dhakate R, Gurunadha RVVS, Durga PM (2015) Hydrochemical assessment of groundwater in alluvial aquifer region, Jalandhar District, Punjab, India. Environ Earth Sci 73:8145-8153

Thivya C, Chidambaram S, Rao MS, Thilagavathi R, Prasanna MV, Manikandan S (2015) Assessment of fluoride contaminations in groundwater of hard rock aquifers in Madurai district, Tamil Nadu (India). Appl Water Sci. https://doi.org/10.1007/s1320 1-015-0312-0

Trivedy RK, Goel PK (1984) Chemical and biological methods for waste Pollution studies. Environ Publ, Karad, pp 35-96

Tyagi SK, Datta PS, Pruthi NK (2009) Hydrochemical appraisal of groundwater and its suitability in the intensive agricultural area of Muzaffarnagar district, Uttar Pradesh, India. Environ Geol $56: 901-912$ 
USSL (1954) Diagnosis and improvement of saline and alkaline soils. United States Salinity Laboratory, US Department of Agriculture, Washington

Vasanthavigar M, Srinivasamoorthy K, Rajiv Ganthi R, Vijayaraghavan K, Sarma VS (2012) Characterisation and quality assessment of groundwater with a special emphasis on irrigation utility: thirumanimuttar sub-basin, Tamil Nadu, India. Arab J Geosci 5:245-258

Venkatesharaju K, Ravikumar P, Somashekar RK, Prakash KL (2010) Physico chemical and bacteriological investigation on the River Cauvery of Kollegal Stretch in Karnataka. J Sci Eng Technol 6(1):50-59

WHO (1988) Guidelines for drinking water supply quality, I recommendation. WHO, Geneva, $\mathrm{p} 2$
WHO (World Health Organisation) (2004) Water sanitation and hygene links to health. WHO press, Geneva

Zhang L, Song X, Xia J, Yuan R, Zhang Y, Liu X, Han D (2011) Major element chemistry of the Huai River basin, China. Appl Geochem 26:293-300

Zhang W, Kinniburgh D, Gabos S (2013) Assessment of groundwater quality in Alberta, Canada using GIS mapping. In: 3rd International conference on medical, biological and pharmaceutical sciences, vol 3, pp 199-203

Publisher's Note Springer Nature remains neutral with regard to jurisdictional claims in published maps and institutional affiliations. 